\title{
Deprival value: information utility analysis
}

\author{
Marco Antonio Pereira \\ Universidade de São Paulo, Faculdade de Economia, Administração e Contabilidade, Departamento de Administração, São Paulo, SP, Brazil \\ Email: mantper@usp.br
}

\begin{abstract}
Alexandre Evaristo Pinto
Universidade de São Paulo, Faculdade de Direito, Departamento de Direito Econômico, Financeiro e Tributário, São Paulo, SP, Brazil Email: alexandre.pinto@usp.br
\end{abstract}

\section{João Estevão Barbosa Neto}

Universidade Federal de Minas Gerais, Faculdade de Ciências Econômicas, Departamento de Contabilidade, Belo Horizonte, MG, Brazil Email: joaoestevaobarbosaneto@gmail.com

\section{Eliseu Martins}

Universidade de São Paulo, Faculdade de Economia, Administração e Contabilidade de Ribeirão Preto, Departamento de Contabilidade, Ribeirão Preto, SP, Brazil

Email: emartins@usp.br

Received on 02.08.2017 - Desk acceptance on 03.11.2017 - $4^{\text {th }}$ version approved on 09.22.2017

\begin{abstract}
This article contributes to the perception that the users' learning process plays a key role in order to apply an accounting concept and this involves a presentation that fits its informative potential, free of previous accounting fixations. Deprival value is a useful measure for managerial and corporate purposes, it may be applied to the current Conceptual Framework of the International Accounting Standards Board (IASB). This study analyzes its utility, taking into account cognitive aspects. Also known as value to the business, deprival value is a measurement system that followed a path where it was misunderstood, confused with another one, it faced resistance to be implemented and fell into disuse; everything that a standardized measurement method tries to avoid. In contrast, deprival value has found support in the academy and in specific applications, such as those related to the public service regulation. The accounting area has been impacted by sophistication of the measurement methods that increasingly require the ability to analyze accounting facts on an economic basis, at the risk of loss of their information content. This development becomes possible only when the potential of a measurement system is known and it is feasible to be achieved. This study consists in a theoretical essay based on literature review to discuss its origin, presentation, and application. Considering the concept's cognitive difficulties, deprival value was analyzed, as well as its corresponding heteronym, value to the business, in order to explain some of these changes. The concept's utility was also explored through cross-analysis with impairment and the scheme developed was applied to actual economic situations faced by a company listed on stock exchange.
\end{abstract}

Keywords: deprival value, impairment, information utility, cognition, measurement.

Correspondence address:

Marco Antonio Pereira

Universidade de São Paulo, Faculdade de Economia, Administração e

Contabilidade, Departamento de Administração

Avenida Professor Luciano Gualberto, 908 - CEP: 05508-010

Cidade Universitária - São Paulo - SP - Brazil 


\section{INTRODUCTION}

The increasing complexity of measurement methods requires, more and more, ability to analyze accounting facts on an economic basis and knowledge of their fundamentals. As an evolutionary process, some methods have been developed through other ones. Knowing them, therefore, involves knowing how things are done over time and due to which reasons. In this approach, facets of thinking, such as cognitive biases and anchorages, may become clear and contribute to grasp its usefulness.

Deprival value is a complex measurement method, developed from another one, with frustrated attempts of normative implementation, but having a rich history of academic discussion, which made the concept survive and unfold in specific applications, as it occurs in the regulatory public service procedures.

This study shows some presentation failures, allowing an improper association with the concept value to the owner, which it stemmed from, that hinder understanding and improving its utility. To do this, this essay introduces the concept's origins and development along with possible cognitive biases that have been accumulated so far. The expected contribution focuses on improving the analytical ability of deprival value users and on exploring its usefulness as a recoverability test, an application not explored by the literature available.

\section{FROM THE DEPRIVAL VALUE'S ORIGIN TO APPLICATION}

\subsection{The Concept's Origin}

The deprival value's origin was assigned to the ideas underlying another concept, value to the owner, developed by Bonbright (1937) for indemnification purposes in judicial proceedings. The measurement is triggered from the loss of an asset whose value (value to the owner) is defined like this:

The value of a property to its owner is identical in amount with the adverse value of the entire loss, direct and indirect, that the owner might expect to suffer if he were to be deprived of the property (Bonbright, 1937, p. 71).

Subjectivity, acknowledged by the author, might be due to the special circumstances of each individual. Thus, there could be no reasonable threshold to this value when considering all direct and indirect losses experienced by an asset's owner.

The study by Bonbright (1937) stands out by its joint view, both of entry and exit values, allowing adequate indemnification to each concrete case.

\subsection{Applying Deprival Value to Accounting}

In the 1960s and 1970s, the development of theories of current and corrected cost application intensified, due to rising inflation. As a result, some accounting standardization bodies issued standards for companies to consider currency value changes in the financial statements or in the specific price of certain assets. Mattessich (1998) reports that deprival value emerged as a practical, broad, but not general solution to the assessment issue.
The Accounting Standards Committee (1980) issued the Statement of Standard Accounting Practice 16 (SSAP 16) - Current Cost Accounting. Whittington (1994) points out that the SSAP 16 required that all listed and large companies use not only historic cost, but accounting criteria at current cost, through deprival value, in the preparation of their financial statements.

According to Weetman (2007), the SSAP 16 has never been widely accepted, although most companies complied with it at first. Although the SSAP 16 was mandatory, it did not have effective coercive. Faced with growing disuse, Whittington (1994) reports that it became optional in 1986 and it was totally revoked in 1988 . The reasons stated: (i) great objection to the recognition of inflation effects in the financial statements; (ii) difficulty in understanding this accounting information by companies and users; and (iii) lower inflation levels (Weetman, 2007).

In the United States of America (USA), the Statement of Financial Accounting Standards 33 - Financial Reporting and Changing Prices (SFAS 33) was issued by the Financial Accounting Standards Board (FASB, 1979), revoked in December 1986. Just as in the United Kingdom (UK), the reasons were: (i) the information was not used by capital market analysts; (ii) the cost of preparing such information was high in relation to the benefits; and (iii) information could be irrelevant or misleading and biased (Whittington, 2007).

Lennard (2010) also points out that, at this time, faced with implementation difficulties, current cost was rejected in accounting advances and experiments because it seemed unrealistic.

Therefore, the main application of deprival value was 
the monetary restating of assets at current costs, and its function was maintaining the firm's capital (Whittington, 1994). This is so because inflation lags the prices of assets acquired in previous times, and when they become cost in the period, this is insufficient to replace the same operational assets. As a consequence, profit for the period will be higher and, if there is no retention of profits, there might be decapitalization, which could affect the ability to generate wealth.

\subsection{Examining the Application of Deprival Value to Accounting}

The first aspect to be examined is ease of association with asset loss. Initially, this might occur through a literal reading of the concept of deprival value: deprivation value. However this association remains in the literature (Baxter, 2003; Lennard, 2010; Macve, 2010; Van Zijl \& Whittington, 2006) and in the normative documents when explaining the concept as a loss value if the company were deprived of using an asset (Accounting Standards Board [ASB], 1999; FASB, 1979). Yet, if measurement served to update the asset's value at current replacement costs in an inflationary environment, how could we think of loss? Therefore, there would be increased nominal value of an asset. Nevertheless, there was consensus on how, objectively, the three baselines for measuring deprival value should be hierarchized:

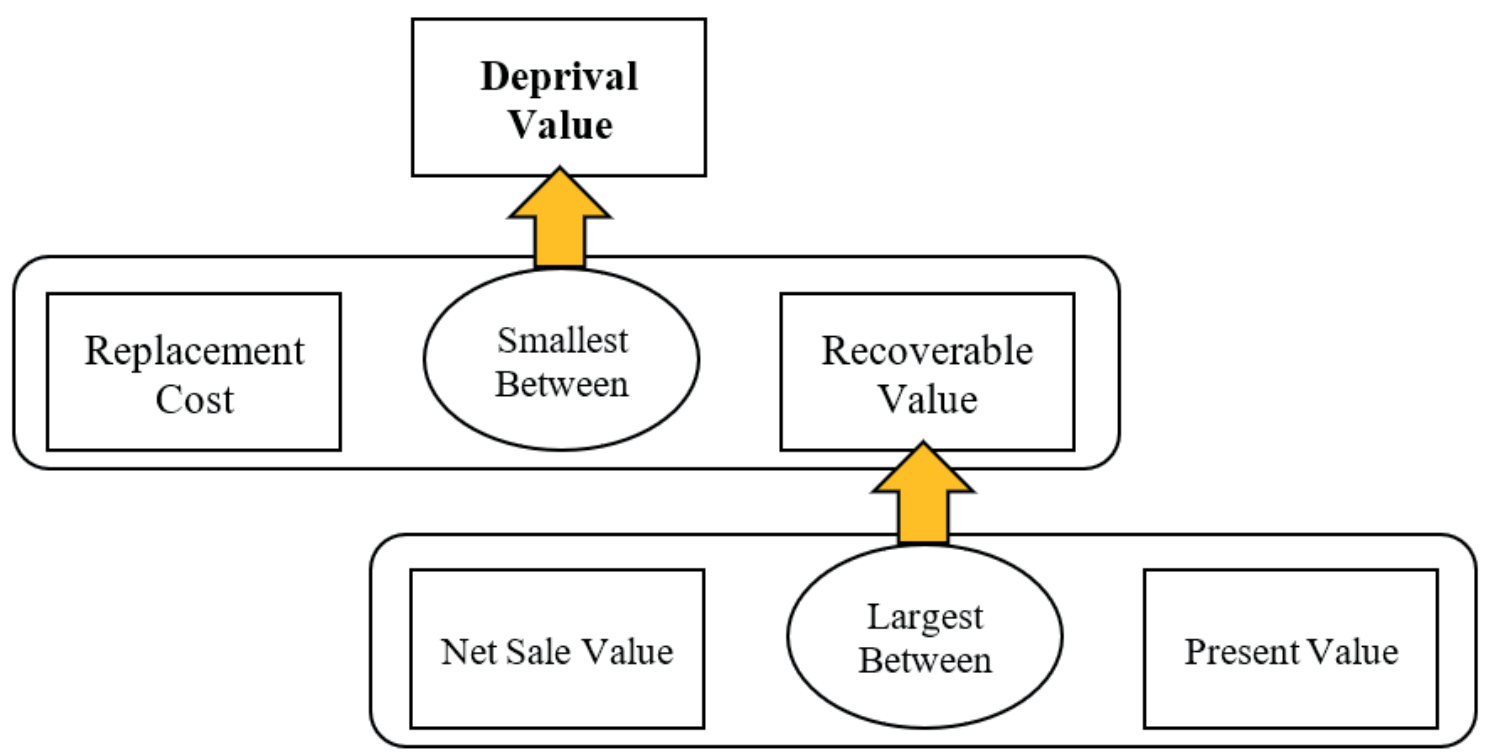

Figure 1 Deprival value determination scheme

Source: Prepared by the authors.

According to Macve (2010), deprival value is formulated as:

$$
\mathrm{DV}+=\operatorname{Min}[\mathrm{RC} ; \operatorname{Max}(\mathrm{NRV} ; \mathrm{PV})]
$$

where: DV+: asset's replacement cost modified by deprival value; RC: replacement cost; NRV: net recoverable value; PV: present value.

To understand the anchoring process through loss and confusion with the value to the owner, an example is provided by a taxi driver who wants to valuate his vehicle after an inflationary period whose value, at a depreciated historic cost, is $\$ 28,000$. What is the deprival value of the taxi? Applying the concept, according to the literature, leads the appraiser to imagine an asset deprivation situation. This cognitive process is criticized by Lennard (2010), due to the tortuous rationale that must be conducted to evaluate the measurement bases, since loss might be just a hypothesis. However, assuming that the appraiser imagines a hypothetical situation of loss: the vehicle hit by another one and resulting in total loss. So, the value of this measurement coincides with the amount of indemnification to be paid to the taxi driver, creating here the first analogy with value to the owner! The three measurement bases could be evaluated as follows: (i) the replacement cost for acquisition of the same vehicle, in the same condition and age, to be used as a taxi; (ii) the taxi's net sale value, if it were sold just before the accident; 
and (iii) present value of future net cash flow arising from the vehicle use as a taxi.

Table 1 provides three situations where each of the measurement bases could become deprival value, according to the determination scheme in Figure 1. In the first situation, the value $\$ 40,000$, equivalent to the replacement cost, might be sufficient for the taxi driver to acquire an identical vehicle and get back to work. In the second, the value $\$ 35,000$, equivalent to present value of the future cash flows, might be the fair value, considering that the taxi driver could obtain this value if he kept working with the vehicle. And, in the third situation, the value $\$ 30,000$ represents the value that the taxi driver would receive when he sold it, higher than what he would get for working with it, but less than the cost of acquiring an identical vehicle.

Table 1 Taxi's deprival value at the valuation time (values in thousand)

\begin{tabular}{lccc}
\hline & & Situation \\
\cline { 2 - 4 } & $\mathbf{1}$ & $\mathbf{2}$ & $\mathbf{3}$ \\
\hline Historic cost & 28 & 28 & 28 \\
Replacement cost & 40 & 40 & 30 \\
Net sale value & 30 & 30 & 35 \\
Present value of cash flows & 80 & 35 & 30 \\
Deprival value & 40 & 35 \\
\hline
\end{tabular}

Source: Prepared by the authors.

But supposing that the taxi driver told the appraiser that his taxi has a $\$ 10,000$ additional affective value, totaling the perceived asset's replacement value $\$ 50,000$, would the appraiser consider the replacement cost as \$ 50,000 ? If he does this, the value to the owner provided by Bonbright (1937) is adopted, which accepts the indirect asset's losses. Fraser (1988) stress that, in the absence of perfect competitive equilibrium and complete markets, only direct losses should be included. Therefore, this could be considered only if a replacement market existed for additional affective value.

Although it has led to deprival value for indemnity purposes, admittedly one of the method's utilities, the objective was determining the taxi's value by considering only economic aspects in the asset-owner relationship. This difficulty to interpret the concept is perceived when Fraser (1988) makes it clear that deprival value and value to the owner are not synonyms and that Bonbright (1937) might had been misinterpreted when the concept of deprival value as a direct derivation from the value to the owner was assigned to him.

Therefore, although the idea of loss has served as a cognitive lever for the method's application and to provide the term deprival value with meaning, its use may restrict information understanding by the company and the user, as it actually occurred, according to Weetman (2007), as mentioned above.

The literature available mentions the term value to the business as synonymous with deprival value (Solomons, 1995; Weetman, 2007; Whittington, 1998). And the SSAP 16 and the SFAS 33 give greater prominence to value to the business, but explain it regarding deprivation of the asset's use, referring to the already known deprival value.

Thus, the second aspect considered is its inadequate presentation, by maintaining the term deprival value rather than value to the business. Taking into account the user's cognition process should be a part of the standardization process. Dearman and Shields (2005) verified that information users may have some type of accounting fixation, as they grasp and address a new measurement basis in the same way as the old one, and this might be more common among users with poorer accounting knowledge, poorer problem-solving skills, or less intrinsic motivation for the subject matter. Therefore, the cognitive anchorage of deprival value in the earlier concept proposed by Bonbright (1937) is not surprising.

The third aspect is that, even though deprival value has been inserted into a general accounting system of current cost measurement, considered as unrealistic, other utilities may emerge from its essence, i.e. value to the business.

\section{EXPLORING THE DEPRIVAL VALUE UTILITY}

Deprival value is also a replacement test similar to the impairment test, although this aspect is not explored in the literature available, regardless Whittington (1998) has pointed out this possibility. However, before comparing the results between these two tests, we present the analysis that aims to provide the context that the appraiser must have (or fail to have) when looking for the elements of deprival value. 


\subsection{Concept's Cognitive Analysis}

Table 2 provides an insight on how an appraiser who is aware of the impairment test could see deprival value through the current information provided and from another perspective of the method, such as value to the business.

Table 2 Cognitive analysis of deprival value

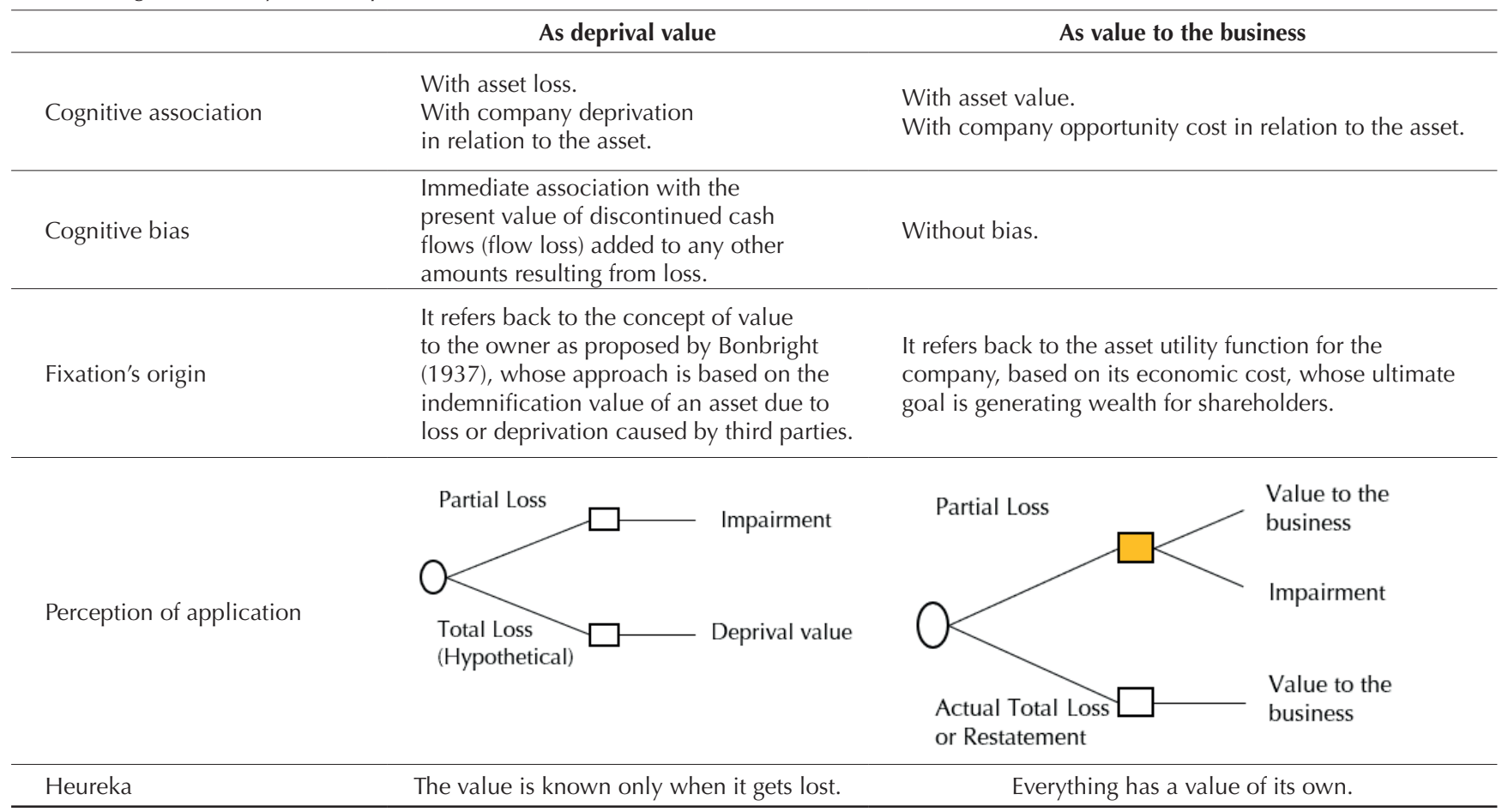

Source: Prepared by the authors.

As deprival value, it is difficult to perceive it as a replacement test, which assesses partial losses, since there would be no way to imagine partial deprivation of an asset.

Nevertheless, as value to the business, the perception of application broadens, supporting the assessment of both an asset that had actual, partial, or total loss and an asset in which it is desired to update at current costs. This measure is presented to the user as a company opportunity cost in relation to the asset, whose value is aligned with the goal of wealth maximization for the shareholder.

\subsection{Analysis of Results of Comparison with Impairment}

Following the approach proposed by Van Zijl and Whittington (2006) and Weetman (2007), the possible results of assessing an asset measured by deprival value using the function:

$$
\mathrm{DV}+=\operatorname{Min}[\mathrm{RC} ; \operatorname{Max}(\mathrm{NRV} ; \mathrm{PV})]
$$

where: DV+: asset's replacement cost modified by deprival value; RC: replacement cost; NRV: net recoverable value; PV: present value.

There are two basic situations described in Table 3. In them, the concept of economic profit is the difference between present value and replacement cost. In the first situation (a), the asset has the potential to generate economic profit, so deprival value is replacement cost. The company wishes to return the asset and continue its activity (i or ii) or to sell it (iii). In the second (b), the asset has the potential to generate economic loss, so deprival value is equal to the replacement cost only if the company, when replacing the asset, can sell it at a profit (iv). Otherwise, it is equal to the net sale value (v) or equal to the present value (vi).

Thus, the function DV+ should represent value to the business more adequately than the historic cost measurement, given the situations described. In this context of assessment, economic rationality dictates that the value of an asset generating profit for the business is its replacement cost. Yet, when the asset ceases to generate economic profit, asset value becomes the value that the entity can recover from it. 
The probability of an asset having its sale value higher than its replacement cost (iv) and/or its value in use (v) is considered to be low, unless the asset is promising to the market and/or the problem is the company's inability to explore the asset and not the asset itself. Thus, deprival value measurements should focus on replacement cost and, in negative situations, on present value.

An asset measured by deprival value might have as a result of book loss:

$$
\text { DV - = Min[Max(NRV; PV) - RC; 0] }
$$

where: DV-: book loss with deprival value; NRV: net recoverable value; $\mathrm{PV}$ : present value; $\mathrm{RC}$ : replacement cost.

The concept of impairment may also be presented as a function of an asset's values. The representation of historic cost modified by impairment may be:

$$
\mathrm{I}+=\operatorname{Min}[\mathrm{HC} ; \operatorname{Max}(\mathrm{NRV} ; \mathrm{PV})]
$$

where: I+: asset's historic cost modified by impairment; $\mathrm{HC}$ : historic cost; NRV: net recoverable value; PV: present value.

An asset assessed by impairment may present the following result of book loss:

$$
\text { I- = Min }[\operatorname{Max}(N R V ; P V)-H C ; 0]
$$

where: I-: book loss with impairment; NRV: net recoverable value; PV: present value; HC: historic cost.

Comparing the measurements of assets and the respective book losses (I+, I-, DV+ and DV-) through the measurements of basic elements (RC/HC, NRV, and

\begin{tabular}{|c|c|c|c|c|c|}
\hline & & $\begin{array}{c}\text { Modified historic } \\
\text { cost }\end{array}$ & $\begin{array}{l}\text { Book } \\
\text { loss }\end{array}$ & $\begin{array}{c}\text { Modified } \\
\text { replacement cost }\end{array}$ & $\begin{array}{l}\text { Book } \\
\text { loss }\end{array}$ \\
\hline Situation & $\begin{array}{c}\text { Measurement } \\
\text { observed }\end{array}$ & I+ & I- & DV+ & DV- \\
\hline \multicolumn{6}{|l|}{ (a) Profit potential } \\
\hline & (i) $P V>N R V>R C$ & $\mathrm{HC}$ & 0 & $\mathrm{RC}$ & 0 \\
\hline & (ii) $\mathrm{PV}>\mathrm{RC}>\mathrm{NRV}$ & $\mathrm{HC}$ & 0 & $\mathrm{RC}$ & 0 \\
\hline and having sale potential & (iii) $N R V>P V>R C$ & $\mathrm{HC}$ & 0 & RC & 0 \\
\hline \multicolumn{6}{|l|}{ (b) Loss potential } \\
\hline \multirow[t]{3}{*}{ and having sale potential } & (iv) $N R V>R C>P V$ & $\mathrm{HC}$ & 0 & $\mathrm{RC}$ & 0 \\
\hline & (v) $\mathrm{RC}>\mathrm{NRV}>\mathrm{PV}$ & NRV & NRV-HC & NRV & NRV-RC \\
\hline & (vi) $R C>P V>N R V$ & PV & $\mathrm{PV}-\mathrm{HC}$ & PV & PV-RC \\
\hline
\end{tabular}
$\mathrm{PV})$, the results are displayed in Table 3.

Table 3 Possible results of deprival value and impairment when $R C=H C$

$D V+=\operatorname{Min}[R C ; \operatorname{Max}(N R V ; P V)] ; D V-=\operatorname{Min}[\operatorname{Max}(N R V ; P V)-R C ; 0]$.

I+ = Min[HC; $\operatorname{Max}(N R V ; P V)] ; I-=\operatorname{Min}[\operatorname{Max}(N R V ; P V)-H C ; O]$.

$D V_{+}$: asset's replacement cost modified by deprival value; $D V$-: book loss with deprival value.

I+: asset's historic cost modified by impairment; I-: book loss with impairment.

$H C$ : historic cost; RC: replacement cost; NRV: net recoverable value; PV: present value.

Source: Prepared by the authors.

Book losses (I- and DV-) are equivalent to the nonrecoverable portion of the asset. It is noticed that the structural difference between the methods is using historic cost or replacement cost, respectively.

Deprival value, by using replacement cost, results in value to the business, which is in essence an asset's opportunity cost for the entity (Mattessich, 1998). By considering specific economic aspects in comparison to measurement based only on historic costs, it constitutes invaluable management information for each assessment exercise. And, unlike the impairment test, deprival value may be applied in an actual or hypothetical total loss situation.
Thus, companies that use historic cost as an ongoing measurement basis may use deprival value $(\mathrm{D}+)$ to show the market a dimension of the asset's economic value to the company.

The information in Table 3 starts from the assumption that replacement cost is equal to historic cost $(\mathrm{RC}=$ $\mathrm{HC}$ ). However, replacement cost may be both lower the higher (more likely) than historic cost. In this case, there is another aspect that differentiates the two measurement systems. Deprival value allows restating the value of an asset in a monetary base, incorporating inflation and other variations pertinent to the asset. 


\subsection{Empirical Application}

Actual situations of partial and total loss were determined based on the Petrobras company. The choice was due to its economic significance and because the facts were widely publicized at the time. From an external perspective, by adopting determination schemes (Figure 1) and the analysis tables presented in the paper (tables 2 and 3), each situation is contextualized and the results presented with impairment.

\subsubsection{Petrobras 2014.}

The year 2014 was remarkable in terms of financial disclosure for Petrobras. Internal and external factors impacted the business, requiring a review of future prospects that affected the assets' recoverable value. The following stand out: (i) decline in oil prices; (ii) national currency devaluation; (iii) problems with infrastructure suppliers; and (iv) lower economic growth (Petrobras, 2014).

In impairment, the company compares the net book value of an individual asset or the cash-generating unit with its respective recoverable amount. The latter is measured through the asset's value in use as a basis because, given the particularities of the company's assets, net sale value is low (Petrobras, 2014).

As explained in the 2014 Annual Report, value in use is estimated having the present value of future cash flows arising from the continuous asset use as a basis, using risk-adjusted weighted average discount rates.

In the financial statements for 2014, Petrobras recognized $\mathrm{R} \$ 44.6$ billion of impairment losses on property, plant, and equipment and intangible assets; assets whose net book value totaled $\mathrm{R} \$ 79.5$ billion had an estimated recoverable value of $\mathrm{R} \$ 34.9$ billion. Thus, the following compositions emerge:

$$
\begin{gathered}
\mathrm{I}+=\operatorname{Min}[\mathrm{HC} ; \operatorname{Max}(\mathrm{NRV} ; \mathrm{PV})]=\operatorname{Min}[79.5 ; \operatorname{Max}(\mathrm{low} ; 34.9)]=34.9 \text { billion R\$ } \\
\mathrm{I}-=\operatorname{Min}[\operatorname{Max}(\mathrm{NRV} ; \mathrm{PV})-\mathrm{HC} ; 0]=\operatorname{Min}[\operatorname{Max}(\text { low } ; 34.9)-79.5 ; 0]=-44.6 \text { billion R\$ }
\end{gathered}
$$

The net sale value (NRV), as admitted by the company, is low and lower than value in use (PV), as observed by the result of impairment. Although the replacement cost (RC) value is not known for determining $\mathrm{D}+$, we may put into question whether the equality between historic cost and replacement cost $(\mathrm{HC}=\mathrm{RC})$ prevails. Given the economic and operational context experienced by the company within this period and the reported book values, we may considered unlikely that replacement cost is lower than historic cost. And, even more unlikely, that replacement cost is lower than value in use. Thus, there is the following composition:

$$
\mathrm{DV}+=\operatorname{Min}[\mathrm{RC} ; \operatorname{Max}(\mathrm{NRV} ; \mathrm{PV})]=\operatorname{Min}[\mathrm{RC} ; \operatorname{Max}(\text { low; 34.9) }]=\mathrm{R} \$ 34.9 \text { billion }
$$

The economic situation described consists in potential economic loss and a low asset sale potential $(\mathrm{RC}>\mathrm{PV}>$ NRV), referring to item (vi) displayed in Table 3.

Thus, the value of these assets for Petrobras or, in other words, their value to the business, is equivalent to value in use at the time of assessment, at the end of 2014. Once the economic situation gets better, it is possible that value in use increases, changing the elements of assessment and leading DV+ to equal replacement cost, again.

\subsubsection{Petrobras 2001.}

In 2001, there was total loss of the oil production platform, the P-36, located in the Campos Basin, Rio de Janeiro State. The company valuates its assets for insurance purposes having replacement cost as a basis, simulating the claims adjuster impact on the operating units and the potential for damage caused (Petrobras, 2001). 
Table 4 Daily report of the news published in the media

\begin{tabular}{|c|c|}
\hline Date and source & News summary \\
\hline $\begin{array}{l}\text { March } 15 \\
\text { (Soares \& Grabrois, 2001) }\end{array}$ & $\begin{array}{l}\text { Day of explosions and interruption of production. } \\
\text { The monthly loss due to suspension of the production of the P-36 platform } \\
\text { can reach US\$ } 50 \text { million. The CFO was not able to tell how long the } \\
\text { platform will take to be restored. He said explosions did not affect any } \\
\text { production equipment. To calculate losses, the price of US\$2 } 20 \text { a barrel of } \\
\text { oil was taken into account, with the oil type Brent at US\$23 a barrel. }\end{array}$ \\
\hline
\end{tabular}

March 15

(Ripardo, 2001)
The P-36 would be able to increase national oil production by $16 \%$. The platform is located in one of the most promising oil fields in Brazil, with reserves estimated at 3 billion barrels.
March 16

(Soares, 2001)
The estimated loss of revenue for the year will be US\$ 450 million. Calculation takes into account the estimated 90,000 barrels per day (bpd) that will no longer be produced.

The production drop will be partly replaced by oil from the Marlim Sul Field. Out of its production, $50 \%$ are exported and they would remain in the domestic market. As it is more viscous, it should be mixed with a lighter, imported oil. Import expenses are also a part of the estimated loss calculation.
March 18

(Mendes, Rodrigues, \& Monken, 2001)
It is studied to accelerate the production by means of the connection of wells in the region, moving equipment from the Roncador Field to the Marlim Sul Field or moving smaller platforms to the Roncador Field, in order to guarantee oil extraction. The start of the P-40 operation was scheduled only for July and peak production for November 2002.
March 19

(Petrobras planeja..., 2001)
Petrobras is considering to increase production in the Marlim Sul Field with the installation of the P-40, which was acquired for US\$ 550 million, which has a maximum capacity of $150,000 \mathrm{bpd}$. This measure aims to reduce the estimated losses of US\$ 60 million per month in oil imports.

Day of sinking and total loss of the P-36.

A new platform would be ready within 2 or 3 years.

March 20

The Minister of Mines and Energy said that Petrobras should order as soon as

(Zimmermann, 2001) possible another platform to replace the P-36. He also admitted the existence of environmental risk, since the platform sank with 1.5 million liters of oil.

March 21

(Santos, 2001)
Petrobras expects to receive, in 3 months, the indemnification of US\$500 million. The estimated loss is US $\$ 450$ million, but officials say the loss could be reduced to US\$300 million. Among the possibilities, putting into operation, in the Roncador Field, one of the two company's idle platforms (P-21 and P-24) or renting a platform in the external market.

Source: Prepared by the authors.

It should be noticed that, in this situation, determining deprival value runs the risk of being confused with value to the owner, if the appraiser concentrates on indirect losses.
Considering the information available, the following composition may be proposed:

$$
\mathrm{DV}+=\operatorname{Min}[\mathrm{RC} ; \operatorname{Max}(\mathrm{NRV} ; \mathrm{PV})]=\operatorname{Min}[500 ; \operatorname{Max}(\text { low } ; \mathrm{HIGH})]=\mathrm{US} \$ 500 \text { million }
$$

The value of the P-36 platform for Petrobras refers to its replacement cost. The basic motive comes from the ability to generate economic profit, making its value in use high. With the asset loss, the company planned to replace it immediately to keep generating net positive cash flow. It falls under item (ii) displayed in Table 3, a situation of potential economic profit and low asset's sale potential $(\mathrm{PV}>\mathrm{RC}>\mathrm{NRV})$.

As a case result, the new capital expenditure was compensated by the receipt of insurance, based on the 
platform's replacement cost, i.e. US\$ 500 million, avoiding the company's market value correction for this reason.
Regarding the impairment assessment, since it is a total asset loss, it is not made.

\section{CONCLUSION}

The normative application of deprival value in the 1980s faced resistance due to difficulty to define measuring elements, but also due to the cognitive bias that was formed. Nowadays, such elements may no longer be seen as so subjective or so difficult to measure.

Also, deprival value constitutes a major tool for managerial, societal, and government control purposes of public service entities (Evans \& Guthrie, 2005; Macve, 2010; Weetman, 2007). It may be applied to assets in use or not and to assets that had partial or total losses. It might represent relevant information for assessing the future perspective of the entity's cash flows, by signaling the context of assets' economic assessment. It may be used as an alternative measurement of assets, enabling the calculation of return on assets adequate to the maintenance objectives of the entity's financial capital. Thus, public service regulators have used deprival value in the nationalization and privatization of public utility services, in determining the value of regulatory capital and in controlling these entities (Evans \& Guthrie, 2005; Grout, Jenkins, \& Zalewska, 2004; Weetman, 2007). But it can also find application in the scope of executory contract assessment (Rouse, 1994) and in indemnification.

By dealing directly with the notion of loss of value, the application of deprival value as a recoverability test was explored, opposing it to the current impairment test based on historic costs. As a result, deprival value proved to be useful both in partial loss situations and in total, actual, or hypothetical loss. Thus, it is understood that exclusive association with asset's loss or deprivation does not result in better cognitive perspective of the concept of deprival value, which is independent of loss in providing the asset's opportunity cost to the company (value to the business), both in normality contexts, in which there might be gain in value or absence of loss, and in operational abnormality contexts, where there might be partial or total asset value loss.

Finally, it is worth noticing that the standards addressing the impairment test do not apply only to assets recorded at historic cost, allowing the application of deprival value in the current Conceptual Framework of the IASB.

\section{REFERENCES}

Accounting Standards Board (1999). Statement of principles for financial reporting. London: ASB.

Accounting Standards Committee (1980). SSAP 16: current cost accounting. Statement of Standard Accounting Practice. London: ASC.

Baxter, W. (2003). The case for deprival value. Edinburgh: Institute of Chartered Accountants of Scotland.

Bonbright, J. C. (1937). The valuation of property: a treatise on the appraisal of property for different legal purpose. New York: McGraw-Hill.

Dearman, D. T., \& Shields, M. D. (2005). Avoiding accounting fixation: determinants of cognitive adaptation to differences in accounting method. Contemporary Accounting Research, 22(2), 351-384.

Evans, L. T., \& Guthrie, G. A. (2005). Risk, price regulation, and irreversible investment. International Journal of Industrial Organization, 23(1-2), 109-128.

Financial Accounting Standards Board (1979). Statement of Financial Accounting Standards n. 33. Financial accounting and changing price. Stamford, CT: FASB.

Fraser, I. A. M. (1988). Deprival value or value to the owner? A clarification. Abacus: A Journal of Accounting, Finance and Business Studies, 24(1), 86-89.
Grout, P. A., Jenkins, A., \& Zalewska, A. (2004). Privatisation of utilities and the asset value problem. European Economic Review, 48(4), 927-941.

Lennard, A. (2010). The case for entry values: a defence of replacement cost. Abacus: A Journal of Accounting, Finance and Business Studies, 46(1), 97-103.

Macve, R. (2010). The case of deprival value. Abacus: A Journal of Accounting, Finance and Business Studies, 46(1), 111-119.

Mattessich, R. (1998). In search of a framework for deprival value and other purpose-oriented valuation methods. Abacus: $A$ Journal of Accounting, Finance and Business Studies, 34(1), 4-7.

Mendes, D., Rodrigues, K., \& Monken, M. H. (2001, March 18). Petrobras quer ampliar produção em Marlim para compensar P-36. Folha de São Paulo. Retrieved from http://www1.folha. uol.com.br/folha/dinheiro/ult91u17103.shtml

Petrobras (2001). Relatório anual. Retrieved from http://www. investidorpetrobras.com.br/pt/relatorios-anuais/relatorio-deadministracao.

Petrobras planeja instalar a P-40 em Marlim Sul (2001, March 19). Folha de São Paulo. Retrieved from http://www1.folha.uol. com.br/folha/cotidiano/ult95u24772.shtml

Petrobras (2014). Relatório anual. Retrieved from http://www. investidorpetrobras.com.br/pt/relatorios-anuais/relatorio-deadministracao. 
Ripardo, S. (2001, March 15). P-36 aumentaria em 16\% produção de petróleo do país, diz Marítima. Folha de São Paulo. Retrieved from http://www1.folha.uol.com.br/folha/dinheiro/ ult91u16904.shtml

Rouse, P. (1994). The recognition of executory contracts. Accounting and Business Research, 25(97), 15-21.

Santos, C. (2001, March 21). Empresa espera receber seguro em até 5 meses. Folha de São Paulo. Retrieved from http://www1. folha.uol.com.br/folha/cotidiano/ult95u25001.shtml

Soares, P. (2001, March 16). Petrobras vai perder US\$ 450 milhões este ano com acidente na P-36. Folha de São Paulo. Retrieved from http://www1.folha.uol.com.br/folha/dinheiro/ ult91u17026.shtml

Soares, P., \& Grabrois, A. P. (2001, March 15). Prejuízo com plataforma será de US\$ 50 milhões mensais, diz Petrobras. Folha de São Paulo. Retrieved from http://www1.folha.uol. com.br/folha/dinheiro/ult91u16918.shl

Solomons, D. (1995). Criteria for choosing an accounting model. Accounting Horizons, 9(1), 42-51.
Van Zijl, T., \& Whittington, G. (2006). Deprival value and fair value: a reinterpretation and a reconciliation. Accounting and Business Research, 36(2), 121-130.

Weetman, P. (2007). Comments on deprival value and standard setting in measurement: from a symposium to celebrate the work of Professor William T. Baxter. Accounting and Business Research, 37(3), 233-242.

Whittington, G. (1994). Current cost accounting: its role in regulated utilities. Fiscal Studies, 15(4), 88-101.

Whittington, G. (1998). Deprival value and price change accounting in the U.K. Abacus: A Journal of Accounting, Finance and Business Studies, 34(1), 28-30.

Whittington, G. (2007). Profitability, accounting theory and methodology. The selected essays of Geoffrey Whittington. Oxford: Routledge.

Zimmermann, P. (2001, March 20). Nova plataforma só deverá ficar pronta em até três anos, diz ministro. Folha de São Paulo. Retrieved from http://www1.folha.uol.com.br/folha/dinheiro/ ult91u17299.shtml 